\title{
Yönetim Kurulu Büyüklüğü, Bağımsız Üye Oranı ve Kadın Üye Oranı İle Finansal Performans İlişkisi
}

\author{
Özgür ATILGAN ${ }^{1}$
}

$\ddot{O} z$

Çalışmanın amacı BISST' deki şirketlerin yönetim kurulu üye sayısı, bă̆ımsız yönetim kurulu üye oranı ve yönetim kurulunda kadın üye oranı ile finansal performans ilişkisini incelemektir. Bu amaçla oluşturulan modelde bağıml değişken olan finansal performansın ölçülmesinde karlılık oranlarından yararlanılmıştır. Çalışmanın sonucuna göre, yönetim kurulu büyüklügü ile varlık getiri oranı (ROA), öz kaynak getiri oranı (ROE) ve EBITDA arasında zayıf ve pozitif yönlü anlamlı ilişki tespit edilirken, bağımsız üye oranı ile varlıkların getiri oranı (ROA) arasında zayıf ve negatif yönlü anlamlı bir ilişki, kadın üye oranı ile ise, EBITDA margin ve satışların getiri oranı (ROS) arasında düşük ve negatif yönlü anlamlı bir ilişki tespit edilmiştir.

Anahtar Kelimeler: Yönetim Kurulu Üye Sayısı, Bağımsız Yönetim Kurulu Üye Oranı, Kadın Yönetim Kurulu Üye Oranı, Karlılık Oranlarl, Finansal Performans.

JEL Sinıflandırma Kodları: M10, M14, M41.

\section{The Relationship Between Board Size, Ratio of Independent Board Members, Ratio of Women Board Members and Financial Performance}

\begin{abstract}
The aim of this study is to investigate the relationship between board size, ratio of independent board members and ratio of women board members and financial performance of BIST (Istanbul Stock Exchange) firms. For this purpose, profitability ratios were used in measuring financial performance which included as dependent variable in the model. The results indicate that there is a weak and positive significant correlation between board size and ROA, ROE and EBITDA, while there is a weak and negative correlation between the ratio of independent board members and ROA and also a weak and negative correlation between the ratio of women in board and EBITDA Margin and ROS.
\end{abstract}

Keywords: Size of Board, Proportion of Independent Board Members, Proportion of Women Board Members, Profitability Ratios, Financial Perfomance.

JEL Classification Codes: M10, M14, M41.

\footnotetext{
${ }^{1}$ Araş.Gör., İstanbul Kültür Üniversitesi, İktisadi ve İdari Bilimler Fakültesi, Girişimcilik Bölümü, o.atilgan@iku.edu.tr
} 


\section{GİRIŞ}

\section{Ö.ATILGAN}

Kurumsal yönetim bir organizasyonun tepesindeki yöneticilerin yönetim kurulu üyeleri tarafından kontrol edildiği, yönetim kurulu yapılanmaları, yönetici teşvikleri ve yöneticileri gözleme gibi mekanizmalarla ilişkili bir yapıdır (Donaldson, 1990: 369:381). Amerika' da 1970' li yılların başından 2000' li yılların başına kadar süregelen dünyanın çeşitli yerlerinde yaşanan şirket skandallarından sonra kurumsal yönetimin özünü oluşturacak çalışmalar yapılmış ve ağırlıklı olarak yönetim kurulu yapılanmalarının üzerinde durulmuştur (Arslantaş, 2012:2). Yönetim kurulları, şirketlerde yöneticilerin hissedarların menfaatleri doğrultusunda hareket etmesini sağlayan en önemli kurumsal yönetim mekanizmalarından biridir. Yöneticilerin atanması, kontrol edilmesi ve işten çıkarılması yönetim kurullarının görevleri arasındadır (Beiner vd., 2004:327-356). İdeal bir yönetim kurulu, işletmenin yönetimini elinde bulunduran ve çoğunluk hisselerine sahip olanların kendi çıkarları doğrultusunda hareket etmesini engelleyerek, azınlık hissedarlarının haklarını savunmada önemli bir rol oynamalıdır (Arosa vd., 2010:236-245). Dolayısıyla, şirketlerin paydaşları ile pay sahiplerinin çıkarlarını örtüştürecek yönetim kurulu yapılanması oluşturmak kurumsal yönetimin uygulanabilmesi için ayrı bir öneme sahiptir (Fama ve Jensen, 1983:327-349).

Literatürde yönetim kurullarının işletme performansına etki eden faktörler olarak, yönetim kurulu yapısı özellikleri öne çıkmaktadır (Anderson ve Reeb, 2004:209-237). Ancak, literatürde yönetim kurulu yapısı ile finansal performans ilişkisini inceleyen birçok çalışma bulunmasına rağmen yönetim kurulu yapısı ile finansal performansın ilişkisi hakkında birbiriyle çelişen sonuçlar ortaya koyulmuştur (Dalton vd.,1998:269-290). Bu bağlamda, bu çalışma kapsamında BİST (Borsa İstanbul) şirketleri için yönetim kurulu yapısı özelliklerinden olan yönetim kurulu büyüklüğü, yönetim kurulunda bağımsız üye oranı ve yönetim kurulunda kadın üye oranının vekalet teorisi ve kaynak bağımlılığı çerçevesi içerisinde finansal performans ile olumlu yönde ilişkisi olup olmadığ 1 sorusu yanıtlanacaktır. Çalışmada, yönetim kurulu üye sayısı, bağımsız üye oranı ve kadın 
üye oranı bilgilerine KAP (Kamu Aydınlatma Platformu)' dan ulaşılmıştır. Finansal performansın ölçülmesinde ise karlılık rasyoları (varlık getiri oranı (ROA), öz kaynak getiri oranı (ROE), satışların getiri oranı ROS), faiz, vergi, amortisman öncesi kar marjı /EBITDA ve faiz, vergi, amortisman öncesi kar marjı /EBITDA margin) kullanılmıştır.

Türkiye' de yönetim kurulu yapısı özellikleri ile yapılan çalışmalar ise genelde eski adı ile İMKB' de yer alan az sayıda ve belirli sektördeki şirket üzerinde yapılmıştır. Bu sebepten dolayı bu çalışmanın literatüre en büyük katkısı, yönetim kurulu yapısı ile finansal performans ilişkisinin güncel veriler (2011-2016) ile büyük bir örneklem (293 şirket) üzerinde analiz edilmesi olacaktır.

Çalışmanın birinci bölümünde kurumsal yönetim ve yönetim kurulu yapısı kavramları üzerinde durulacak, ve kurumsal yönetim teorileri açıklanacak ve literatür taraması yapılacaktır. Çalışmanın ikinci bölümünde ise araştırmanın amacı doğrultusunda araştırmanın modeli kurulacak, hipotezler oluşturulacak ve son olarak metodoloji kısmında hipotezler test edilecek ve bulgular paylaşılacaktır.

\section{KURUMSAL YÖNETIM PARADİGMASI}

“ Kurumsal Yönetim” kavramı bir şirketten direkt olarak menfaat sağlayan pay sahipleri ile şirket yönetiminden dolaylı olarak etkilenen paydaşlar arasında meydana gelebilecek muhtemel çıkar çatışmalarını uyumlaştırmaya yönelik mekanizmalar seti olarak tanımlanmaktadır (Freeman ve Reed, 1983:88-106). Şirket yönetimlerini iyileştirmeye yönelik standart oluşturma ihtiyacı 1970' li yıllarda yaşanan Watergate skandalı ile başlamış, ardından 1990' l1 yılların başından itibaren ortaya çıkan Enron, WorldCom, Xerox, Parmalat, Ahold ve Yanguanxia gibi şirket skandallarından sonra kurumsal yönetimin esasını oluşturmak için özellikle yönetim kurulu yapılanmaları üzerinde durulmuştur. 1991 yılında Londra Menkul Kıymetler Borsası tarafından hazırlanan Cadbury Raporu ilerleyen yıllarda kurumsal yönetim ilkelerinin altyapısını oluşturacak ilk çalışma olarak kabul edilmektedir (Arslantaş ve Fındıklı, 2010:258-275).1999 senesinde OECD kurumsal yönetime k1lavuzluk edecek kurumsal yönetim ilkelerini 


\section{Ö.ATILGAN}

yayımlamış ve 2000 y1lında Türkçeye çevrilmiştir (Koçel, 2011:456). SPK 2003 yılında ilk defa o zamanki ismi ile İMKB (İstanbul Menkul Kıymetler Borsası) deki şirketler için kurumsal yönetim anlayışının benimsetilmesine yönelik olarak kurumsal yönetim ilkelerini yayımlamış ve 2005 yılından itibaren borsa şirketleri için “ Kurumsal Yönetim Uyum Raporu” hazırlamalarını istemiştir (Akdoğan ve Boyacıoğlu, 2010: 11-30). 2007 y1lında ise kurumsal yönetim uyum raporuna göre "kurumsal yönetim ilkeleri uyum derecelendirme notu en az 6 olan" şirketlerin yer aldığı İMKB Kurumsal Yönetim Endeksi oluşturulmuştur (Toraman ve Abidoğlu, 2008: 96-109). Kurumsal yönetim ilkeleri SPK tarafindan yayınlandığı tarihten itibaren 2011 yılına kadar gönüllülük esasına dayandırılmış olunup, bu süre zarfında borsa şirketlerine bir bakıma kurumsal yönetime geçiş süresi tanımıştır. Ancak özellikle 2011 yılından başlanarak yayınlanan Tebliğler ile bazı kurumsal yönetim ilkelerine uyulması zorunlu hale getirilirken bazı ilkelerde gönüllülük esası devam ettirilmiştir. Uyulması zorunlu tutulan ilkeler daha çok yönetim kurulu yapısı ile ilgili olup bu şekilde yönetim kurulunun etkinliğinin arttırılması amaçlanmıştır. Bunun en önemli nedenlerinden biri de İMKB Kurumsal Yönetim Endeksi' nde bulunan şirketlerin en düşük derecelendirme notun "yönetim kurulu" bölümünden almış olmalarıdır (Arslantaş, 2012:3).

\subsection{Kurumsal Yönetimin Yönetim Kurulu Büyüklüğü ve Yönetim} Kurullarında Bağımsız Üye Oranı ve Kadın Üye Oranı ile İlgili Düzenlemeleri

Yönetim kurulu, üyeleri pay sahipleri tarafindan seçilen ve esas görevi şirketin faaliyetleri konusunda karar alan yöneticileri pay sahiplerinin menfaatleri doğrultusunda hareket edip etmedikleri hususunda gözetleyen merci olup en önemli kurumsal yönetim mekanizmalarından biri olarak sayılmaktadır (Fama, 1980: 288-307). Yöneticilerin kanuna, esas sözleşmeye, iç düzenlemelere ve yönetim kurulunun belirlediği yazılı talimatlara göre uygun davranışlarda bulunup bulunmadıklarını denetlemek yönetim kurulunun görevleri arasındadır (Arslantaş, 2012:3). Özellikle gelişmekte olan ülkelerdeki mevcut yönetim kurulu yapısı, kurumsal yönetim ilkelerince önerilen ideal yapı ile uyumlu olmamaktadır. Genel olarak işletmeler üzerinde aile sahipliği ve yönetiminin hakim olduğu bu ülkelerde, 
yönetim kurulları, ailenin işletmeler üzerindeki hakimiyetini sürdürmek için başvurduğu bir araç haline gelmektedir (Öktem ve Gökşen, 2010:258). Dolayısıyla, kurumsal yönetim ilkeleri özellikle şirket hissedarlığının fazla dağınık olmadığı ülkelerde yönetim kurullarının çoğunluk hisselerini elinde bulunduran pay sahiplerinin, azınlık hisse sahiplerini ve diğer şirket paydaşlarını mağdur etmesini engellemek amacı ile borsa şirketlerinde yönetim kurullarının yapısal özelliklerini değiştirecek uygulamalar getirmiştir (Baysinger ve Butler, 1985:101-124).

Bununla birlikte, kurumsal yönetim ilkelerinin yönetim kurullarının yapısal özelliklerini değiştirecek uygulamaları bazı teorik temellere dayanmaktadır. $\mathrm{Bu}$ teorilerden vekalet teorisine göre yönetim kurullarının başlıca görevi, hisse sahipleri (vekalet verenler) ile icracı yöneticiler (vekiller) arasındaki olası çıkar çatışmalarını en aza indirmek amacıyla yöneticilerin sürekli gözlemleyip, kontrol etmektir (Eisenhardt, 1989:57-74). Dolayısıyla, vekalet teorisi pay sahipleri ile yöneticiler arasındaki çatışmalarının giderilmesinin bağımsız yönetim kurulu üyelerinin çoğunlukta olduğu yönetim kurulu yapılanması ile çözülebileceğini öne sürmektedir (Nicholson ve Kiel, 2007:585-608). Bunun nedeni, bağımlı üyelerin işletme sahiplerinin ya da işletmedeki yöneticilerin isteklerine razı göstereceği, bağımsız üyelerin ise olası çıkar çatışmalarında daha tarafsız bir tutum sergileyeceği ve böylece azınlık hissedarların haklarını savunabileceğidir (Wagner vd., 1998:655-676). SPK' nın 2012 y1lında yayınlanan Seri: IV No:57 say1lı "Kurumsal Yönetim Tebliğ" ine göre "yönetim kurulunda bağımsız üye sayısı toplam üye sayısının üçte birinden az olmaması" zorunlu hale getirilmiştir (SPK, 2012:21). Ayrıca yine vekalet teorisi yönetim kurulu üye sayısının fazla olduğu yönetim kurullarında yöneticilerin yönetim kurulunda kendi çıkarları doğrultusunda davranmalarının zorlaşacağını ileri sürmektedir (Zahra ve Pearce, 1989:291-334). SPK' nın 2011 tarihinde resmi gazetede yayınlanan Seri: IV No:56 sayıl1 “ Kurumsal Yönetim Tebliğ” ine göre "yönetim kurulu üye sayısının en az beş olması" zorunlu tutulmuştur (SPK, 2011:21).

Kaynak bağımlılı̆̆ teorisine göre ise organizasyon sadece çevresine adapte olmak zorunda olan pasif bir sosyal yapı değil, aynı zamanda yaşamını sürdürmek 


\section{Ö.ATILGAN}

için gerekli kaynaklara ulaşmak için yaptığı hamleler ile çevresine etki eden sosyal bir yapıdır (Aldrich ve Pfeffer, 1976:79-105). Dolayısıyla, yönetim kurulu üyelerinin bir görevi de organizasyonun dış çevresiyle ilişki kurması ve kişisel bağlantılarıyla organizasyonlara kaynak bulmaya yardımcı olmaktır (Boyd, 1990:419-430). Bu bağlamda, kaynak bağımlılı̆g teorisi de vekalet teorisine benzer şekilde bağımsız yönetim kurulu üyelerinin çoğunlukta olduğu ve yönetim kurulu üye sayısının fazla olduğu yönetim kurullarının şirketin çevresindeki aktörlerle ilişkilerinde avantaj sağlayabileceğini iddia etmektedir (Pfeffer, 1972:218-228). Vekalet teorisine ek olarak kaynak bağımlılığı teorisi yönetim kurulunun şirketin dış çevresinden kaynak temin etmesinden yola çıkarak yönetim kurulu çeşitliliğinin şirket için kritik kaynaklara ulaşmasını kolaylaştıracağını varsayarak şirket performansını arttıracağını iddia etmektedir (Hillman vd., 2000:235-356). Bununla birlikte, Türkiye’ de yönetim kurulu çeşitliliği ile ilgili yapılan çalışmalarda daha çok cinsiyete odaklanılmıştır. Bunun nedeni ise, Türkiye' de kadınların aktif biçimde çalışma hayatında yer almalarına rağmen yönetim kurulu üyeliği gibi üst düzey yönetici pozisyonlarında kadınların oranının erkeklere göre düşük seviyede olmasıdır (Aycan,2004:453-477). Kurumsal yönetim kadın üyelerin yönetim kurullarında daha fazla yer alması gerektiğini ileri sürmektedir. Bunun en önemli nedenleri kadın üyelerin, yönetim kurullarına çeşitlilik getirmesi, yönetim kuruluna yeni fikirler ve stratejiler sunabilmeleri ve gücü paylaşmaya meyilli olmaları nedeniyle şirketlerde CEO ların hegemonyasını azaltabilmeleridir (Burgess ve Tharenen, 2002:39-49). Kadın üyeler erkek üyelere göre yönetim kurulu toplantılarına katılmada daha az devamsızlık yapmakta, entelektüel anlamda bağımsız üye tanımına uymaya daha yatkın olmakta ve bu sebepten dolayı da şirket performansına olumlu etki yaptıkları öne sürülmektedir (Adams ve Ferreira, 2009:291-309). SPK 2011 yılında yayınladığı Seri: IV No:57 sayılı tebliği ile borsada işlem gören şirketlerin yönetim kurullarında en az bir kadın üye bulundurulmasını zorunlu olmamakla birlikte tavsiye niteliğinde bir ilke olarak getirmiştir (SPK, 2011: 21). Daha sonra ise, 2014 y1lında yayınlanan (II-17.1 nolu) kurumsal yönetim tebliğinde yönetim kurullarında kadın üye oranının \%25, den az 
olmaması kaydıyla yeni bir hedef koyulmuş ve şirketlere bu hedefe ulaşılması için politikalar oluşturmaları tavsiye edilmiştir (SPK, 2014: 9).

\subsection{Literatürde Yönetim Kurulu Büyüklüğü, Yönetim Kurullarında} Bağımsız Üye Oranı ve Kadın Üye Oranı ile Finansal Performans İlişkisi

Performans bir şirketin başarısını ölçmeye sağlayan, şirketin amaçlarına ne derece ulaştığını açıklayan, içinde birçok boyut bulunduran bir kavramdır (Akal, 2002:1). Finansal performans ise, şirketin önceden belirlenen karlıl1k hedeflerinin ne ölçüde gerçekleştirildiğinin değerlendirilmesidir. Finansal performans göstergeleri şirketin faaliyetlerinin şirket karlılığına katkısını göstermektedir (Kaplan ve Norton, 1996:79). Bu bağlamda, finansal oranlar bir şirketin finansal performansını değerlendirmede en sık kullanılan göstergeler arasında sayılmaktadır (Akgüç, 1998:20). Literatürde finansal oranlar yardımıyla yönetim kurulu büyüklüğ̈̈, yönetim kurullarında bağımsız üye oranı ve yönetim kurullarında kadın üye oranı ile finansal performans ilişkisini inceleyen birçok çalışma bulunmaktadır.

Yermack’ ın 1996 yılında yaptığı çalışmada Forbes dergisinde yer alan 452 şirketin yönetim kurulu büyüklüğü ve bağımsız yönetim kurulu üye oranı ile finansal performans ilişkisi araştırılmıştır. 1984-1991 yılları arasındaki veriler kullanılarak yapılan çalışmada finansal performans Tobin' Q, ROA ve ROS oranları kullanılarak ölçülmüştür. Çalışmanın sonucuna göre ise, 0,01 anlamlılık düzeyinde yönetim kurulu büyüklüğü ile ROA arasında çok zayıf ( $-0,03)$ ve negatif yönlü bir ilişki ve yine yönetim kurulu büyüklüğü ile ROS arasında çok zayıf $(-0,02)$ ve negatif yönlü bir ilişki tespit edilmiştir. Bağımsız üye oranı ile ROA ve ROS arasında ise anlamlı bir ilişki tespit edilmemiştir (Yermack, 1996: 185-211).

Conyon ve Peck ise 1998 yılında yaptıkları çalışmada Fransa' da 60, Hollanda' da 21, Danimarka' da 22, İtalya' da 21 ve İngiltere' de 481 şirket ile yaptıkları çalışmada yönetim kurulu büyüklüğü ile finansal performans ilişkisini araştırmışlardır. Finansal performansın ROE ve Tobin's Q ile ölçüldüğü çalışmada tüm ülkelerdeki şirketler için yönetim kurulu büyüklüğü ile finansal performans 


\section{Ö.ATILGAN}

arasında zayıf ve negatif yönlü bir ilişki tespit edilmiştir (Conyon ve Peck, 1998: 291-304).

Dehaene ve diğerlerinin 2001 yılında Belçika' da 122 işletme üzerinde yaptığ 1 çalışmada yönetim kurulu yapısı ile finansal performans ilişkisi araştırılmıştır. Çalışmada finansal performans ROA ve ROE ile ölçülmüsştür. Çalışmanın sonucuna göre 0,05 anlamlılık düzeyinde bağımsız yönetim kurulu üye oranı ile ROA arasında anlamlı bir ilişki tespit edilmezken, bağımsız yönetim kurulu üye oranı ile ROE arasında zayıf ve pozitif yönlü bir ilişki tespit edilmiştir (Dehaene vd., 2011:392-393).

Kiel ve Nicholson' in 2003 yılında Avustralya' daki 348 şirket üzerinde yaptı̆̆ çalışmada yönetim kurulu yapısı ile finansal performans ilişkisini araştırılmıştır. Çalışmada finansal performans ROA ile ölçülmüştür. Çalışmanın sonucuna göre, hem yönetim kurulu büyüklüğünün hem de bağımsız yönetim kurulu üye oranının 0,05 anlamlılık düzeyinde ROA ile anlamlı bir ilişkisi tespit edilmemiştir (Kiel ve Nicholson, 2003: 189-205).

Lam ve Lee ise 2008 yılında Hong Kong' ta 123 halka açık şirket üzerinde yaptıkları çalışmada yönetim kurulu büyüklüğü ve bağımsız üye oranı ile finansal performans ilişkisini araştırmışlardır. Finansal performansın ölçülmesinde ROA ve ROE kullanılmıştır. Çalışmanın sonucuna göre, yönetim kurulu büyüklüğü ile ROA arasında 0,05 anlamlılık düzeyinde zayıf ve negatif bir ilişki tespit edilirken yönetim kurulu büyüklüğü ile $\mathrm{ROE}$ arasında anlamlı bir ilişki tespit edilmemiştir. Çalışmanın bir diğer sonucu ise 0,10 anlamlılık düzeyinde bağımsız yönetim kurulu üye oranı ile ROA arasında zayıf ve negatif yönlü bir ilişki tespit edilmesidir. Bağımsız yönetim kurulu üye oranı ile ROE arasında ise anlamlı bir ilişki tespit edilmemiştir (Lam ve Lee, 2008:299-316).

Adams ve Ferreira 2009 yılında 1996-2003 dönemi verileri ile ABD’ de 1939 şirket ile yaptıkları çalışmada yönetim kurulu çeşitliliği ile finansal performans ilişkisini araştırmıştır. Çalışmada finansal ROA ve Tobin's q ile ölçülmüştür. Çalışmanın sonucuna göre, yönetim kurulunda kadın üye oranı ile ROA arasında 
zayıf $(0,05)$ ve negatif yönlü bir ilişki tespit edilmiştir (Adams ve Ferreira, 2009: 291-309).

Jackling ve Johl' un 2009 yllında Hindistan' da Borsa' da işlem gören 180 şirket üzerinde yaptıkları çalışmada yönetim kurulu yapısı ile finansal performans ilişkisini araştırmışlardır. Çalışmada finansal performans ROA ile ölçülmüştür. Çalışmanın sonucuna göre, bağımsız yönetim kurulu üye oranı ile ROA arasında anlamlı bir ilişki tespit edilmezken, yönetim kurulu büyüklügü ile ROA arasında 0,01 anlamlılık düzeyinde zayıf $(0,32)$ ve pozitif yönlü bir ilişki tespit edilmiştir (Jackling ve Johl, 2009:492-509).

Ramdani ve van Witteloostuijn' in 2010 yllında Endonezya' da 66, Güney Kore'de 111, Malezya'da 75 ve Tayland' da 61 şirket ile yaptı̆̆ çalışmada yönetim kurulu yapısı ile finansal performans ilişkisi araştırılmıştır. Çalışmada finansal performans ROA ile ölçülmüştür. Çalışmanın sonucuna göre, bağımsız yönetim kurulu üye oranı ile ROA arasında zayıf $(0,283)$ ve pozitif yönlü bir ilişki tespit edilmiştir (Ramdani ve Van Witteloostuijn, 2010: 607-626).

Darmadi ise 2010 yılında Endonezya' da borsada işlem gören 169 şirket ile yaptığ çalışmada kullanarak yönetim kurulu çeşitliliği ile finansal performans ilişkisini araştırmıştır. Çalışmada finansal performans ROA ile ölçülmüştür. Çalışmanın sonucuna göre, yönetim kurulunda kadın üye oranı ile ROA arasında anlamlı bir ilişki tespit edilmemiştir (Darmadi,2010: 1627-1637).

Alvarez ve diğerlerinin 2010 yılında Madrid Borsası' nda işlem gören 117 şirket için yönetim kurulu çeşitliliği ve finansal performans ilişkisini araştırmıştır. Çalışmada finansal performans ROA, ROE ve ROS ile ölçülmüştür. Çalışmanın sonucuna göre, 0,01 anlamlılık düzeyinde yönetim kurulunda kadın üye oranı ile ROA, ROE ve ROS arasında orta düzeyde negatif yönlü bir ilişki tespit edilmiştir (I.G. Alvarez vd., 2010:53-88).

Böhren ve Ström ise Norveç’te 2010 yılında Oslo Borsası' na kayıtllı 203 şirket ile yaptıkları çalışmada yönetim kurulu çeşitliliği ile finansal performans ilişkisini araştırmıştır. Çalışmada finansal performans ROA, ROS ve Tobin's q ile 


\section{Ö.ATILGAN}

ölçülmüştür. Çalışmanın sonucuna göre, 0,01 anlamlılık düzeyinde yönetim kurulunda kadın üye oranı ile ROA arasında zayıf $(-0,08)$ ve negatif, yönetim kurulunda kadın üye oranı ile ROS arasında zayıf $(-0,08)$ ve negatif ve yönetim kurulunda kadın üye oranı ile Tobin's q arasında zayıf $(-0,04)$ ve negatif ilişki tespit edilmiştir (Böhren ve Ström, 2010:1281-1308).

Uchida ise 2011 yılında Japonya' da 775 şirket ile yaptığı çalışmada 2002-2007 verilerini kullanarak yaptığı çalışmada yönetim kurulu büyüklüğü ile finansal performans ilişkisini araştırmışır. Çalışmada finansal performans ROA ile ölçülmüştür. Çalışmanın sonucuna göre, 0,05 anlamlılık düzeyinde yönetim kurulu büyüklüğü ile ROA arasında anlamlı bir ilişki tespit edilmemiştir (Uchida, 2011:562-573).

Şengür ve Püskül, Türkiye’ de 2011 yılında İMKB Kurumsal Yönetim İlkeleri’ nde yer alan 24 işletme üzerinde yaptıkları çalışmada yönetim kurulu yapısı ile finansal performans ilişkisi araştırılmıştır. Çalışmada finansal performans ROA, ROE, fiyat kazanç oranı (Price- Earning Ratio), hisse başına kazanç (Earnings per Share) ve hisse senedi getirisi (stock return) kullanılmıştır. Çalışmanın sonucunda yapılan t-testi analizine göre 0,05 anlamlılık düzeyinde yönetim kurulunda bağımsız üye sayısı fazla olan şirketlerin ROA ve ROE lerinin bağımsız üye sayısı az olan şirketlere göre daha düşük olduğu tespit edilmiştir (Şengür ve Püskül, 2011:45).

Koerniadi ve Tourani-Rad' in 2012 yılında Yeni Zelanda Borsası' da işlem gören 182 halka açık şirket üzerinde yaptıkları çalışmada yönetim kurulu büyüklüğü ve bağımsız yönetim kurulu üye oranı ile finansal performans ilişkisi incelenmiştir. Finansal performans ROA ve ROE ile ölçülmüştür. Çalışmanın sonucuna göre 0,01 anlamlılık düzeyinde bağımsız yönetim kurulu üye oranı ile ROA arasında zayıf $(-0,11)$ ve negatif yönlü bir ilişki, bağımsız yönetim kurulu üye oranı ile ROE arasında ise, zayıf $(-0,21)$ ve negatif yönlü bir ilişki tespit edilmiştir. Ayrıca çalışmada 0,05 anlamlılık düzeyinde, yönetim kurulu büyüklüğü ile ROA arasında zayıf $(-0,01)$ ve negatif bir ilişki ve 0,01 anlamlılık düzeyinde 
yönetim kurulu büyüklüğü ile ROA arasında zayıf $(-0,02)$ ve negatif bir ilişki tespit edilmiştir (Koerniadi ve Tourani-Rad, 2012:3-18).

Ocak' in ise 2013 yılında Türkiye' de 2008-2011 dönemi için 111 şirket ile yaptığı çalışmada yönetim kurulu çeşitliliği ile finansal performans ilişkisini araştırılmıştır. Çalışmada finansal performans ROA ile ölçülmüştür. Çalışmanın sonucuna göre, 0,05 anlamlılık düzeyinde yönetim kurulunda kadın üye oranı ile ROA arasında zayıf $(0,07)$ ve pozitif yönlü bir ilişki tespit edilmiştir (Ocak, 2013:107-126).

Swastika ise 2013 yılında Endonezya Borsası' na içki ve gıda sektöründe faaliyet gösteren 51 şirket ile yaptığı çalışmada kurumsal yönetim, şirket büyüklüğü ve finansal performans arasındaki ilişkiyi araştırmıştır. Finansal performans ROA ile ölçülmüştür. Çalışmanın sonucuna göre, 0,05 anlamlılık düzeyinde yönetim kurulu büyüklügü ile ROA arasında pozitif yönlü anlamlı bir ilişki ortaya çıkmıştır (Swastika, 2013:77-82).

Karayel ve Doğan ise Türkiye' de 2014 yılında yaptıkları çalışmada BİST 100 Endeksi' nde yer alan şirketler için 2009-2012 dönemi verilerini kullanarak yönetim kurulu çeşitliliği ile finansal performans ilişkisini araştırmışlardır. Çalışmada finansal performans ROE ve Tobin's q ile ölçülmüştür. Çalışmanın sonucuna göre, yönetim kurulunda kadın üye oranı ile ROE ve Tobin's q arasında anlamlı bir ilişki tespit edilmemiştir (Karayel ve Doğan: 2014:75-88).

Topal ve Doğan ise Türkiye' de 2014 yılında, 2002-2012 dönemi verilerini kullanarak Türkiye' de BİST' de yer alan 136 şirket üzerinde yaptıkları çalışmada yönetim kurulu büyüklüğü ile finansal performans ilişkisini araştırmıştır. Finansal performans ROA ve ROE kullanılmıştır. Çalışmanın sonucuna göre 0,05 anlamlılık düzeyinde yönetim kurulu büyüklüğü ile ROA arasında zayıf $(0,14)$ ve pozitif yönlü bir ilişki tespit edilirken, yönetim kurulu büyüklüğü ile ROE arasında anlamlı bir ilişki tespit edilmemiştir (Topal ve Doğan, 2014:74-79).

Okan ve diğerlerinin Türkiye' de 2014 yılında BİST' de işlem göre 83 şirketin 2011 yılı verilerini kullanarak yaptığı çalışmada yönetim kurulu yapısı ile finansal 


\section{Ö.ATILGAN}

performans ilişkisini incelemişlerdir. Çalışmada finansal performans ROA ile ölçülmüştür. Çalışmanın sonucuna göre, yönetim kurulu büyüklüğü ile ROA arasında 0,05 anlamlılık düzeyinde zayıf $(0,23)$ ve pozitif yönlü bir ilişki tespit edilirken, bağımsız yönetim kurulu üye oranı ile ROA arasında 0,10 anlamlılık düzeyinde zayıf (-207) ve negatif bir ilişki tespit edilmiştir (Okan vd., 2014:3978).

Johl ve diğerleri ise 2015 yılında Malezya Borsası' na kayıtlı 700 şirket üzerine yaptıkları çalışmada yönetim kurulu özellikleri ve finansal performans ilişkisini araştırmışlardır. Çalışmada finansal performans ROA ile ölçülmüştür. Çalışmanın sonucuna göre 0,05 anlamlılık düzeyinde yönetim kurulu büyüklüğü ile ROA arasında zayıf ve pozitif yönlü bir ilişki tespit edilirken, bağımsız yönetim kurulu üye oranı ile ROA arasında anlamlı bir ilişki tespit edilmemiştir (Johl vd.,2015: 239-243).

Ntim ve diğerlerinin 2015 yılında Güney Afrika Borsası' na kayıtlı 169 imalat şirketi ile yaptığı çalışmada yönetim kurulu büyüklüğü ile finansal performans ilişkisi incelenmiştir. Çalışmada finansal performans ROA ve Tobin's Q ile ölçülmüştür. Çalışmanın sonucuna göre, 0,01 anlamlılık düzeyinde yönetim kurulu büyüklüğü ile ROA arasında zayıf $(0,04)$ ve pozitif yönlü bir ilişki tespit edilmiştir (Ntim vd., 2015:194-220).

Aytekin ve Sönmez ise Türkiye' de 2016 yllında 2010-2014 dönemi verilerini kullanarak BİST' de işlem gören 35 şirket ile yaptıkları çalışmada kurumsal yönetim uygulamaları ile şirket performansı ilişkisini incelemişlerdir. Çalışmada şirket performansı ROA ve ROE ile ölçülmüştür. Çalışmanın sonucuna göre, yönetim kurulu büyüklüğü ve yönetim kurulunda yer alan bağımsız üye oranı ile ROA arasında anlamlı bir ilişki tespit edilmemiştir. Ayrıca, 0,01 anlamlılık düzeyinde yönetim kurulu büyüklüğü ile ROE arasında zayıf ve pozitif yönde bir ilişki tespit edilirken, bağımsız üye oranı ile ROE arasında anlamlı bir ilişki tespit edilmemiştir (Aytekin ve Sönmez, 2016:32-42). 
Otluoğlu ve diğerleri Türkiye' de 2016 yılında yaptıkları çalışmada BİST 100 Endeksi' nde yer alan 49 şirket için 2010-2015 dönemi verilerini kullanarak yönetim kurulu çeşitliliği ile finansal performans ilişkisini araştırmışlardır. Çalışmada finansal performans ROA, ROE ve Tobin's q ile ölçülmüştür. Çalışmanın sonucuna göre, yönetim kurulunda kadın üye oranı ile ROA arasında anlamlı bir ilişki tespit edilmezken, 0,10 anlamlılık düzeyinde yönetim kurulunda kadın üye oranı ile ROE arasında zayıf $(0,03)$ ve pozitif yönlü bir ilişki, benzer şekilde 0,10 anlamlılık düzeyinde yönetim kurulunda kadın üye oranı ile Tobin's q arasında ise zayıf $(0,31)$ ve negatif yönlü bir ilişki tespit edilmiştir (Otluoğlu vd., 2016: 749-758).

Ek 1' de Yönetim kurulu büyüklüğü ile finansal performans ilişkisini inceleyen çalışmaların sonuçları tablo halinde gösterilmiştir.

Yukarıdaki paragraflarda da görüldüğü gibi literatürde yönetim kurulu büyüklüğü, yönetim kurulunda bağımsız üye oranı ve yönetim kurulunda kadın üye oranı ile finansal performans ilişkisini inceleyen çalışmaların sonuçları birbirinden farklılık göstermektedir. Dolayısıyla, vekalet teorisinin ve kaynak bağımlılı̆g 1 teorisinin tüm çalışmalarda desteklenmediği anlaşılmaktadır. Daha önce literatürde Türkiye ile ilgili yapılan çalışmalarda da yönetim kurulu büyüklüğü, yönetim kurulunda bağımsız üye oranı ve yönetim kurulunda kadın üye oranı ile finansal performans ilişkisini inceleyen çalışmalar bulunmasına rağmen, bu çalışmaların sonuçları da birbiriyle çelişmektedir.

Tablo 1' de göze çarpan bir diğer husus ise bazı çalışmalarda finansal performansın Tobin's q ile ölçülmüş olmasıdır. Ancak bu çalışmada Tobin's q finansal performans göstergelerinden biri olarak kullanılmamıştır. Bunun nedeni Tobin's q' nun hesaplanmasının tek bir yönteminin olmaması ve literatürde çeşitli akademisyenler tarafından farklı şekilde hesaplanmış olmasıdır. Lindenberg ve Ross, Mc Connel ve Servaes, Morck, Lang, Stulz ve Walkling, Lee ve Tompkins, Chung ve Pruitt çalışmalarında Tobin's q oranını hesaplamada farklı yaklaşımlar denemiştir (Canbaş vd.,2005: 24-36). Dolayısıyla, bu çalışmada ROA, ROE ve ROS' un yanında EBITDA ve EBITDA Margin kullanılacaktır. EBITDA net 


\section{Ö.ATILGAN}

faaliyet karına amortisman ve itfa giderlerinin eklenmesiyle elde edilmektedir(Alcalde vd., 2013:201). Finansal performansın ölçülmesinde EBITDA' nın kullanılmasının en büyük avantajı şirketlerin ödediği vergi miktarını göz ardı ettiği için farklı sektörlerden şirketlerin karlılığını karşılaştırma imkanı sunabilmesidir (Toroman ve Körpi, 2015:45). EBITDA Margin ise EBITDA’ nın toplam hasılata (satışlara) bölünmesiyle elde edilmektedir (Pervan ve Visic, 2012:218).

\section{YÖNETIM KURULU BÜYÜKLÜĞÜ, BAĞIMSIZ ÜYE ORANI VE KADIN ÜYE ORANI İLE FİNANSAL PERFORMANS İLIŞKISSINE YÖNELIKK BİR ARAŞTIRMA}

$\mathrm{Bu}$ bölümde araştırmanın amacı ve önemi, araştırmanın modeli, değiş̧kenleri ve hipotezleri ile araştırmanın metodolojisi ve bulgularına yer verilmiştir.

\subsection{Araştırmanın Amacı ve Önemi}

Araştırmanın amacı, BİST’ de yer alan şirketlerin yönetim kurulu büyüklüğü, yönetim kurulunda bağımsız üye oranı ve yönetim kurulunda kadın üye oranı ile finansal performans ilişkisini araştırmaktır. Bu konu ile Türkiye' de yapılan çalışmalar en fazla 136 şirket ile yapılmıştır. Bu bağlamda, bu çalışmanın önemi BİST' de işlem gören ve finansal raporları 2011-2016 dönemi arasında ifşa edilen tüm sektörlerden toplam 293 şirket ile yönetim kurulu büyüklüğü, yönetim kurulunda bağımsız üye oranı ve yönetim kurulunda kadın üye oranı ile finansal performans ilişkisinin incelenecek olmasıdır. KAP' ta kayıtlı 506 borsa şirketi bulunmasına rağmen, bunlardan yalnızca 293' ünün finansal raporları 2011-2016 dönemi arasında ifşa edilmiş̧ir. Finansal performansın hesaplanmasında 5 yılın ortalamasının alınmasının sebebi rasyo analizlerinin 5 yıllık trendi izlenerek bir şirketin finansal durumu üzerine değerlendirme yapılabilmesi ve finans analistlerinin iflas riski bulunan şirketleri 5 y 1 llık trendin sonunda tespit edebilmesidir (Tükenmez vd., 1999:416). Daha önce Türkiye' de yapılan çalışmalarda güncel veriler ile bu büyüklükteki bir örneklem ile çalışılmamıştır. 
Dolayısıyla bu çalışmanın, örneklem büyüklüğü ve güncel verileri kullanması bakımından literatüre katkı sağlayabileceği öngörülmektedir.

\subsection{Araştırmanın Modeli, Değişkenleri ve Hipotezleri}

Araştırmanın modeli Şekil 1' de gösterilmiştir. Araştırmada finansal performans bağımlı değişken, yönetim kurulu büyüklüğü, yönetim kurulunda bağımsız üye oranı ve yönetim kurulunda kadın üye oranı ise bağımsız değişken olarak modele dahil edilmiştir.

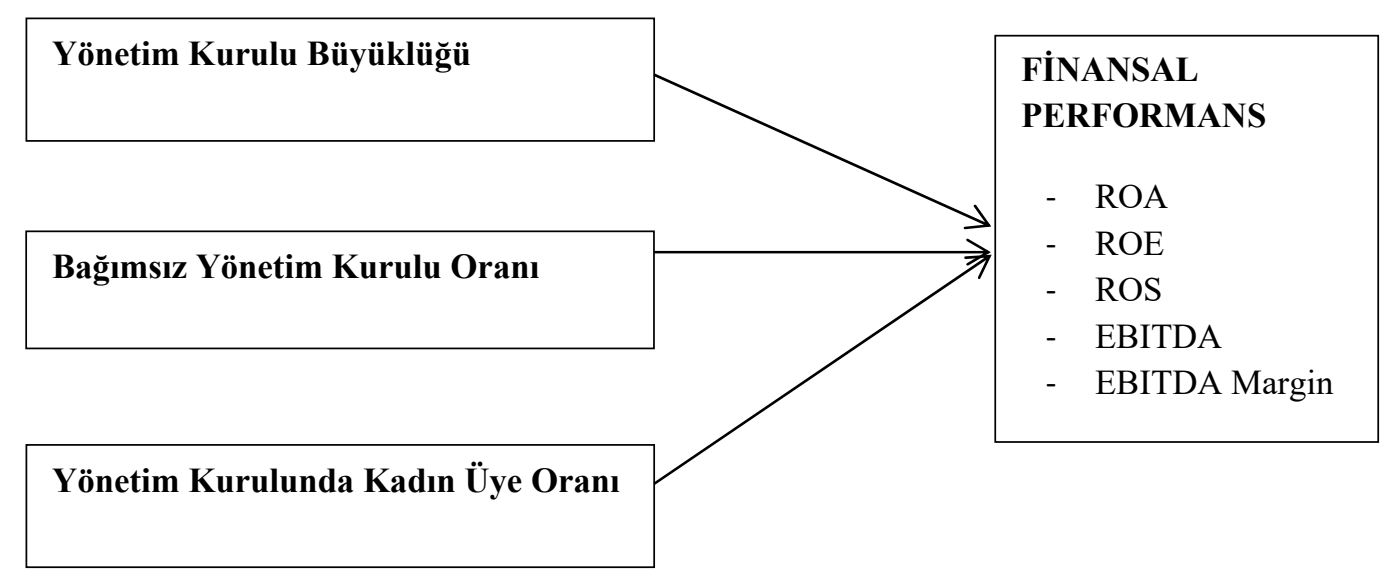

Şekil 1:Araştırmanın Modeli

Kurulan model doğrultusunda aşağıdaki 3 temel hipotez ve bu 3 temel hipoteze bağl1 15 alt hipotez oluşturulmuştur.

$1 \mathrm{H}_{1}$ : Yönetim kurulu büyüklüğü ile finansal performans arasında pozitif anlamlı bir ilişki vardır.

$1 \mathrm{H}_{1 \mathrm{a}}$ : Yönetim kurulu büyüklüğü ile ROA arasında pozitif anlamlı bir ilişki vardır.

$1 \mathrm{H}_{1 b}$ : Yönetim kurulu büyüklüğü ile ROE arasında pozitif anlamlı bir ilişki vardır.

$1 \mathrm{H}_{1 \mathrm{c}}$ : Yönetim kurulu büyüklüğü ile ROS arasında pozitif anlamlı bir ilişki vardır. 


\section{Ö.ATILGAN}

$1 \mathrm{H}_{1 \mathrm{~d}}$ : Yönetim kurulu büyüklüğü ile EBITDA arasında pozitif anlamlı bir ilişki vardır.

$1 \mathrm{H}_{1 \mathrm{e}}$ : Yönetim kurulu büyüklüğ̈̈ ile EBITDA Margin arasında pozitif anlamlı bir ilişki vardır.

$2 \mathrm{H}_{1}$ : Bağımsız yönetim kurulu üye oranı ile finansal performans arasında pozitif anlamlı bir ilişki vardır.

$2 \mathrm{H}_{1 \mathrm{a}}$ : Bağımsız yönetim kurulu üye oranı ile $\mathrm{ROA}$ arasında pozitif anlamlı bir ilişki vardır.

$2 \mathrm{H}_{1 b}$ : Bağımsız yönetim kurulu üye oranı ile ROE arasında pozitif anlamlı bir ilişki vardır.

$2 \mathrm{H}_{1 \mathrm{c}}$ : Bağımsız yönetim kurulu üye oranı ile $\mathrm{ROS}$ arasında pozitif anlamlı bir ilişki vardır.

$2 \mathrm{H}_{1 \mathrm{~d}}$ : Bağımsız yönetim kurulu üye oranı ile EBITDA arasında pozitif anlamlı bir ilişki vardır.

$2 \mathrm{H}_{1 \mathrm{e}}$ : Bağımsız yönetim kurulu üye oranı ile EBITDA Margin arasında pozitif anlamlı bir ilişki vardır.

$3 \mathrm{H}_{1}$ : Yönetim kurulunda kadın üye oranı ile finansal performans arasında pozitif anlamlı bir ilişki vardır.

$3 \mathrm{H}_{1 \mathrm{a}}$ : Yönetim kurulunda kadın üye oranı ile ROA arasında pozitif anlamlı bir ilişki vardır.

$3 \mathrm{H}_{1 b}$ : Yönetim kurulunda kadın üye oranı ile $\mathrm{ROE}$ arasında pozitif anlamlı bir ilişki vardır.

$3 \mathrm{H}_{1 \mathrm{c}}$ : Yönetim kurulunda kadın üye oranı ile ROS arasında pozitif anlamlı bir ilişki vardır.

$3 \mathrm{H}_{1 \mathrm{~d}}$ : Yönetim kurulunda kadın üye oranı ile EBITDA arasında pozitif anlamlı bir ilişki vardır. 
$3 \mathrm{H}_{1 \mathrm{e}}$ : Yönetim kurulunda kadın üye oranı ile EBITDA Margin arasında pozitif anlamlı bir ilişki vardır.

\subsection{Araştırmanın Metodolojisi ve Bulguları}

Çalışmada ikincil verilerden yararlanılmış ve nicel analiz teknikleri kullanılmıştır. $\mathrm{Bu}$ doğrultuda ilk olarak finansal tabloları 2011-2016 dönemi arasında ifşa edilmiş olan 293 şirketin yönetim kurulu büyüklüğü, yönetim kurulunda bağımsız üye oran ve yönetim kurulunda kadın üye oranı bilgilerine KAP' tan ulaşılmıştır. Aşağıda Tablo 1' de 293 BİST şirketinin yönetim kurulu büyüklüğü, yönetim kurulunda bağımsız üye oran ve yönetim kurulunda kadın üye oranına ait aritmetik ortalama ve standart sapma değerleri verilmiştir.

Tablo 1. BİST Şirketlerinin Ortalama Yönetim Kurulu Büyüklüğü, Yönetim Kurulunda Bağımsız Üye Oranı ve Yönetim Kurulunda Kadın Üye Oranı Rakamları ve Standart Sapmas1

\begin{tabular}{|c|c|c|}
\hline & Aritmetik Ortalama & Standart Sapma \\
\hline Yönetim Kurulu Büyüklüğü & 7,13 & 2,32 \\
\hline Yönetim Kurulunda Bağımsız Üye Oranı & 0,29 & 0,11 \\
\hline Yönetim Kurulunda Kadın Üye Oranı & 0,14 & 0,15 \\
\hline
\end{tabular}

Tablo 1' den anlaşıldığg gibi BİST' de yer alan 293 şirketin ortalama yönetim kurulu büyüklüğü 7 dir. Dolayısıyla şirketlerin genel olarak SPK' nın 2011 tarihinde resmi gazetede yayınlanan Seri: IV No:56 sayılı “ Kurumsal Yönetim Tebliğ" ine göre "yönetim kurulu üye sayısı en az 5 olmalı" koşuluna uydukları gözlemlenmektedir. Yönetim kurulunda bağımsız üye oranının ise ortalama olarak 0,29 olduğu gözlemlenmektedir. Bu bakımdan şirketlerin çoğunun SPK' nın 2012 yılında yayınlanan Seri: IV No:57 sayılı "Kurumsal Yönetim Tebliğ" ine göre “yönetim kurulunda bağımsız üye sayısı toplam üye sayısının üçte birinden az 


\section{Ö.ATILGAN}

olmaması" koşuluna da uyum sağladıkları öne sürülebilmektedir. Yönetim kurulunda kadın üye oranının ise ortalama olarak 0,14 olduğu görülmektedir. $\mathrm{Bu}$ durum, şirketlerin hala SPK' nın 2014 yılında yayınlanan (II-17.1 nolu) kurumsal yönetim tebliğinde yönetim kurullarında kadın üye oranının \%25' den az olmaması hedefine 2016 yılı itibariyle henüz ulaşamadığına işaret etmektedir. Kısacası, BİST şirketlerinin SPK tarafindan koyulmuş olan zorunlu ilkelere büyük oranda uyum sağlarken, tavsiye niteliğinde olan ilkelere henüz tam anlamıyla uyum sağlayamadığı öne sürülebilir.

Tablo 1' de BİST şirketlerinin ortalama yönetim kurulu büyüklüğü, yönetim kurulunda bağımsız üye oranı ve yönetim kurulunda kadın üye oranı gösterildikten sonra, 293 şirketin 2011-2016 dönemi arasında tek tek ROA, ROE, ROS, EBITDA ve EBITDA Margin değerleri hesaplanmış, 5 yıllık aritmetik ortalaması alınmış ve standartlaştırma işlemi yapılmıştır. Farklı sektörlerde bulunan işletmelerin finansal rasyolarına ait veri setindeki değerlerin ortalaması ve varyansı arasında önemli farklılıklar olduğu düşünüldüğü için bu farklılıkları gidermek amacıyla standardizasyon işleminin yapılması uygun bulunmuştur. Buna göre, finansal rasyo verilerinin standartlaştırılmasında bir değişkene ait her bir değerden veri setinin ortalama değeri çıkartılarak elde edilen sonucun veri setinin standart sapmasına bölünmesi ile bulunan değerler kullanılmıştır. Böylece, farklı büyüklüklerde olan değerlerin diğer değerlere göre fazla ya da eksik ağırlıklandırılmasının önüne geçilmiştir (Kılıç vd., 2011:32).

Finansal rasyolara ait veriler standartlaştırıldıktan sonra BİST (Borsa İstanbul)' de yer alan 293 şirketin yönetim kurulu büyüklüğü, yönetim kurulunda bağımsız üye oranı ve yönetim kurulunda kadın üye oranı ile ile finansal performansları arasındaki ilişkiyi tespit etmek amacı ile $1 \mathrm{H}_{1}, 2 \mathrm{H}_{1}$ ve $3 \mathrm{H}_{1}$ temel hipotezleri ve bunlara ait alt hipotezlerin test edilmesi amaciyla Pearson Korelasyon Analizi yapılmıştır. Tablo 2' de Pearson Korelasyon Analizi sonuçlarına yer verilmiştir. 
Tablo 2. Değişkenler Arasındaki Pearson Korelasyon Katsayıları

\section{Korelasyon}

\begin{tabular}{|c|c|c|c|c|c|c|c|c|}
\hline & 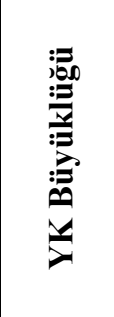 & 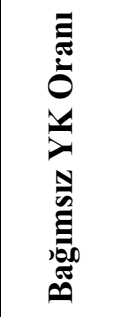 & 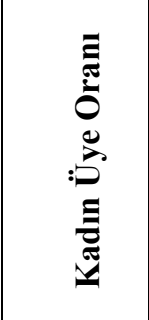 & 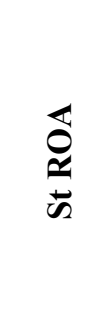 & 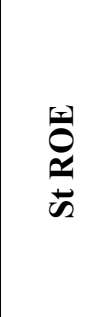 & $\begin{array}{l}\mathscr{2} \\
\stackrel{\infty}{\mathscr{n}} \\
\ddot{\infty}\end{array}$ & 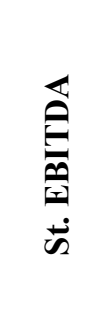 & 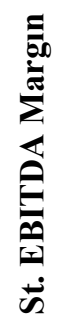 \\
\hline YK Büyüklüğ̈̈̈ & 1 & & & & & & & \\
\hline $\begin{array}{l}\text { Bağımsız YK } \\
\text { Oranı }\end{array}$ &,$- 172^{* *}$ & 1 & & & & & & \\
\hline Kadın Üye Oranı &,$- 126^{*}$ &,- 066 & 1 & & & & & \\
\hline ROA &, $181^{* *}$ &,$- 161^{* * *}$ &,- 074 & 1 & & & & \\
\hline ROE &, $144^{*}$ &,- 105 &,- 070 &, $279^{* *}$ & 1 & & & \\
\hline ROS & ,066 &,- 040 &,$- 122^{*}$ &, $261^{* *}$ & ,084 & 1 & & \\
\hline EBITDA &, $198^{* *}$ &,- 021 &,- 040 &, $147^{*}$ & ,061 &, 042 & 1 & \\
\hline EBITDA Margin &, 058 &,- 063 &,$- 126^{*}$ &, $252^{* *}$ & ,082 &, $990^{* *}$ & ,042 & 1 \\
\hline \multicolumn{9}{|c|}{ **. Korelasyon 0.01 düzeyinde anlamlı } \\
\hline *. Korelasyon & $0.05 \mathrm{di}$ & zeyinde & nlamlı & & & & & \\
\hline
\end{tabular}

Tablo 2' de görüldüğü gibi 0,01 anlamlılık düzeyinde yönetim kurulu büyüklüğü ile ROA arasında zayıf $(0,181)$ ve pozitif yönlü bir ilişki, 0,05 anlamlılık düzeyinde yönetim kurulu büyüklüğu ile ROE arasında zayıf $(0,144)$ ve 


\section{Ö.ATILGAN}

pozitif yönlü bir ilişki ve 0,01 anlamlılık düzeyinde yönetim kurulu büyüklüğü ile EBITDA arasında zayıf $(0,198)$ ve pozitif yönlü bir ilişki tespit edilmiştir. Yönetim kurulu büyüklüğü ile, ROS ve EBITDA Margin arasında ise anlamlı bir ilişki tespit edilmemiştir. Dolayısıyla, $1 \mathrm{H}_{1 \mathrm{a}}, 1 \mathrm{H}_{1 \mathrm{~b}}$ ve $1 \mathrm{H}_{1 \mathrm{~d}}$, alt hipotezleri kabul edilirken, $1 \mathrm{H}_{1 \mathrm{c}}$ ve $1 \mathrm{H}_{1 \mathrm{e}}$ alt hipotezleri ise reddedilmiştir. Bu sebepten dolayı, $1 \mathrm{H}_{1}$ temel hipotezi kısmen kabul edilmiştir. Bağımsız yönetim kurulu üye oranı ile ROA arasında ise 0,01 anlamlılık düzeyinde zayıf (-161) ve negatif bir ilişki tespit edilirken, bağımsız yönetim kurulu üye oranı ROE, ROS, EBITDA ve EBITDA Margin arasında anlamlı bir ilişki tespit edilmemiştir. Dolayısıyla, $2 \mathrm{H}_{1 \mathrm{a}}, 2 \mathrm{H}_{1 \mathrm{~b}}, 2 \mathrm{H}_{1 \mathrm{c}}$, $2 \mathrm{H}_{1 \mathrm{~d}}$ ve $2 \mathrm{H}_{1 \mathrm{e}}$ alt hipotezleri reddedildiği için $2 \mathrm{H}_{1}$ temel hipotezi de reddedilmiştir. Ayrıca, yönetim kurulunda kadın üye oranı ile ROS arasında 0,05 anlamlılık düzeyinde zayıf $(-0,122)$ ve negatif bir ilişki ve yönetim kurulunda kadın üye oranı ile EBITDA Margin arasında zayıf $(-0,126)$ ve negatif bir ilişki tespit edilmiştir. Yönetim kurulunda kadın üye oranı ile ROA, ROE ve EBITDA arasında ise anlamlı bir ilişki tespit edilmemiştir. Dolayısıyla, $3 \mathrm{H}_{1 \mathrm{a}}, 3 \mathrm{H}_{1 \mathrm{~b}}, 3 \mathrm{H}_{1 \mathrm{c}}, 3 \mathrm{H}_{1 \mathrm{~d}}$ ve $3 \mathrm{H}_{1 \mathrm{e}}$ alt hipotezleri reddedildiği için $3 \mathrm{H}_{1}$ temel hipotezi de reddedilmiştir.

$1 \mathrm{H}_{1 \mathrm{a}}, 1 \mathrm{H}_{1 \mathrm{~b}}$ ve $1 \mathrm{H}_{1 \mathrm{~d}}$, alt hipotezleri kabul edilirken ikinci tip hata olup olmadığının kontrol edilmesi amacıyla ikinci tip hata olma olasılı̆̆ 1 aşağıda tablo 3' de gösterilmiştir.

Tablo 3. $1 \mathrm{H}_{1 \mathrm{a}}, 1 \mathrm{H}_{1 \mathrm{~b}}$ ve $1 \mathrm{H}_{1 \mathrm{~d}}$, alt hipotezlerinin ikinci tip hata olasılıkları

\begin{tabular}{|l|c|c|c|c|r|r|r|}
\hline $\begin{array}{c}\text { Dependent } \\
\text { Variable ROA }\end{array}$ & \multicolumn{7}{|c|}{} \\
\hline \multicolumn{1}{|c|}{ Source } & df & $\begin{array}{c}\text { Mean } \\
\text { Square }\end{array}$ & F & Sig. & $\begin{array}{c}\text { Partial Eta } \\
\text { Squared }\end{array}$ & $\begin{array}{c}\text { Noncent. } \\
\text { Parameter }\end{array}$ & $\begin{array}{c}\text { Observed } \\
\text { Power }^{\mathrm{b}}\end{array}$ \\
\hline $\begin{array}{l}\text { Corrected } \\
\text { Model }^{\mathrm{a}}\end{array}$ & 14 & 2,988 & 2,998 &, 000 &, 121 & 42,113 &, 941 \\
\hline Intercept $^{\text {YK }}$ & 1 &, 902 &, 983 &, 268 &, 004 & 1,014 &, 172 \\
\hline Buyukluğu & 14 & 2,988 & 2,998 &, 000 &, 121 & 42,113 &, 941 \\
\hline Error & 278 &, 920 & & & & & \\
\hline Total & 293 & & & & & & \\
\hline Corrected Total & 292 & & & & & & \\
\hline $\begin{array}{c}\text { a. R } \\
\text { Squared }=, 121\end{array}$ & & & & & & & \\
\hline
\end{tabular}


Dokuz Eylül Üniversitesi İktisadi ve İdari Bilimler Fakültesi Dergisi Cilt:32, Sayl:2, Yll:2017, ss. 315-354

\begin{tabular}{|c|c|c|c|c|c|c|c|}
\hline $\begin{array}{l}\text { b. } \\
\text { Computed } \\
\text { using alpha=,05 }\end{array}$ & & & & & & & \\
\hline $\begin{array}{c}\text { Dependent } \\
\text { Variable ROE }\end{array}$ & & & & & & & \\
\hline Source & $\mathrm{df}$ & $\begin{array}{l}\text { Mean } \\
\text { Square }\end{array}$ & $\mathrm{F}$ & Sig. & $\begin{array}{c}\text { Partial Eta } \\
\text { Squared }\end{array}$ & $\begin{array}{l}\text { Noncent. } \\
\text { Parameter }\end{array}$ & $\begin{array}{l}\text { Observed } \\
\text { Power }^{b}\end{array}$ \\
\hline $\begin{array}{l}\text { Corrected } \\
\text { Model }^{\mathrm{a}}\end{array}$ & 14 & 2,891 & 2,994 &, 000 &, 117 & 41,164 & ,932 \\
\hline Intercept & 1 & ,902 & ,978 & ,259 & ,004 & 1,022 & , 179 \\
\hline YK Buyukluğu & 14 & 2.891 & 2,994 &, 000 &, 117 & 41,164 & ,932 \\
\hline Error & 278 & ,923 & & & & & \\
\hline Total & 293 & & & & & & \\
\hline Corrected Total & 292 & & & & & & \\
\hline $\begin{array}{l}\text { a. R Squared = } \\
, 117\end{array}$ & & & & & & & \\
\hline $\begin{array}{l}\text { b. Computed } \\
\text { using alpha=,05 }\end{array}$ & & & & & & & \\
\hline $\begin{array}{l}\text { Dependent } \\
\text { Variable } \\
\text { EBITDA }\end{array}$ & & & & & & & \\
\hline Source & $\mathrm{df}$ & $\begin{array}{l}\text { Mean } \\
\text { Square }\end{array}$ & $\mathrm{F}$ & Sig. & $\begin{array}{l}\text { Partial Eta } \\
\text { Squared }\end{array}$ & $\begin{array}{l}\text { Noncent. } \\
\text { Parameter }\end{array}$ & $\begin{array}{l}\text { Observed } \\
\text { Power }^{b}\end{array}$ \\
\hline $\begin{array}{l}\text { Corrected } \\
\text { Model }^{\mathrm{a}}\end{array}$ & 14 & 3,020 & 3,348 &, 000 & , 144 & 46,876 & ,999 \\
\hline Intercept & 1 & ,897 & ,995 & ,319 & ,004 & ,995 & , 169 \\
\hline YK Buyukluğu & 14 & 3,020 & 3,348 & $000^{\prime}$ & ,144 & 46,876 & 999 \\
\hline Error & 278 & ,902 & & & & & \\
\hline Total & 293 & & & & & & \\
\hline Corrected Total & 292 & & & & & & \\
\hline $\begin{array}{l}\text { a. R Squared = } \\
, 144\end{array}$ & & & & & & & \\
\hline $\begin{array}{l}\text { b. Computed } \\
\text { using alpha=,05 }\end{array}$ & & & & & & & \\
\hline
\end{tabular}

Yukarıda Tablo 3' de görüldüğü gibi ROA' nın bağımlı değişken, yönetim kurulu büyüklügünün ise bağımsız değişken olduğu $1 \mathrm{H}_{1 \mathrm{a}}$ alt hipotezine ait ikinci tip hata olasılı̆ğ $0,06(1-0,941)$ dır. Aynı şekilde ROE' nin bağımlı değişken, yönetim kurulu büyüklüğünün ise bağımsız değişken olduğu $1 \mathrm{H}_{1 b}$ alt hipotezine 


\section{Ö.ATILGAN}

ait ikinci tip hata olasılığ 0,07 (1- 0,932) iken, EBITDA' nın bağımlı değişken, yönetim kurulu büyüklüğünün ise bağımsız değişken olduğu $1 \mathrm{H}_{1 \mathrm{~d}}$ alt hipotezine ait ikinci tip hata olasılı̆g $10,001(1-0,999)$ dir. Dolayısıly $1 \mathrm{H}_{1 \mathrm{a}}, 1 \mathrm{H}_{1 \mathrm{~b}}$ ve $1 \mathrm{H}_{1 \mathrm{~d}}$ alt hipotezlerinde ikinci tip hata yapma olasılıkları göz önünde bulundurulduğunda her üç alt hipotez için de ikinci tip hata yapma olasılıklarının makul düzeylerde olduğu düşünüldüğünden çalışmanın örneklem hacminin yeterli olduğu kanısına varılmıştır.

\section{SONUÇ}

Yönetim kurulu, yöneticilerin paydaşların menfaatleri doğrultusunda hareket edip etmediklerini kontrol eden merci olduğu için önemli kurumsal yönetim mekanizmalarından biri olarak sayılmaktadır. Yönetim kurulu büyüklüğü, yönetim kurulunda bağımsız üye oranı ve yönetim kurulunda kadın üye oranı yönetim kurulu yapısının önemli unsurlarındandır. Bu sebeple, kurumsal yönetim, şirket paydaşları ile pay sahiplerinin çıkarlarını örtüştürecek bir yönetim kurulu yapılanması oluşturmak için yönetim kurulu büyüklüğü, yönetim kurulunda bağımsız üye oranı ve yönetim kurulunda kadın üye oranı ile ilgili bazı düzenlemeler getirmiştir. $\mathrm{Bu}$ düzenlemelerden, yönetim kurulu büyüklügüü ile yönetim kurulunda bağımsız üye oranı ile ilgili olan düzenlemeler zorunlu olurken, yönetim kurulunda kadın üye oranı ile ilgili olan düzenleme gönüllülük esasına dayanmaktadır. Bununla birlikte, bu düzenlemelerin tamamı teorik temellere dayanmaktadır. Vekalet teorisi ve kaynak bağımlılı̆g 1 teorisi bu teoriler arasında öne çıkmaktadır. Vekalet teorisi, yönetim kurulu üye sayısının fazla olduğu yönetim kurullarında yöneticilerin yönetim kurulunda kendi çıkarları doğrultusunda davranmalarının zorlaşacağını ve bağımsız yönetim kurulu üyelerinin çoğunlukta olduğu yönetim kurulu yapılanması ile pay sahipleri ile yöneticiler arasındaki çatışmalarının azaltılmasının mümkün olabileceğini ileri sürmektedir. Kaynak bağımlılı̆g bağımsız yönetim kurulu üyelerinin çoğunlukta olduğu ve yönetim kurulu üye sayısının fazla olduğu yönetim kurullarının şirketin çevresindeki aktörlerle daha iyi ilişki kurmasını kolaylaştırabileceğini varsaymaktadır. Ayrıca, kaynak bağımlılığı 
teorisi şirketin dış çevresinden kaynak temin etmesinden yola çıkarak yönetim kurulu üye çeşitliliğinin ve özellikle yönetim kurullarında kadın üye oranının arttırılmasının şirketin kritik kaynaklara ulaşmasını kolaylaştırabileceğini ön görmektedir.

$\mathrm{Bu}$ bağlamda, literatürde vekalet teorisi ve kaynak bağımlılı̆̆ teorileri çerçevesinde yönetim kurulunun büyüklüğü, yönetim kurulunda bağımsız yönetim kurulu oranı ve yönetim kurulunda kadın üye oranı ile finansal performans ilişkisini inceleyen bir çok çalışma bulunmasına rağmen, bu çalışmalar tutarlı sonuçlar ortaya koyamamaktadır. Türkiye' de de daha önce yönetim kurulunun büyüklüğü, yönetim kurulunda bağımsız yönetim kurulu oranı ve yönetim kurulunda kadın üye oranı ile finansal performans ilişkisini inceleyen çalışmalar bulunmasına rağmen, bu çalışmalar söz konusu değişkenler arasındaki ilişkiyi belirli sektörden şirketler için araştırmışlardır. Bu çalışmanın Türkiye' de yapılan diğer çalışmalardan farkı ve önemi ise, söz konusu değişkenler arasındaki ilişkiyi, daha büyük bir örneklem (293 şirket) ile güncel veriler (2011-2016 dönemi) ile incelemiş olmasıdır.

Çalı̧̧manın sonuçlarından ilki, yönetim kurulu büyüklüğünün arttıkça finansal performansın da kısmen ve az da olsa artış göstermesidir. Yönetim kurulu büyüklüğü ile ROA arasında 0,01 anlamlılık düzeyinde zayıf $(0,181)$ ve pozitif bir ilişki, yönetim kurulu büyüklüğü ile ROE arasında 0,05 anlamlılık düzeyinde zayıf $(0,144)$ ve pozitif bir ilişki ve yönetim kurulu büyüklüğü ile EBITDA arasında 0,01 anlamlılık düzeyinde zayıf $(0,198)$ ve pozitif bir ilişki tespit edilmiş olmasıdır. Dolayısıyla bu çalışmanın sonucu, yönetim kurulu büyüklüğü ile finansal performans ilişkisi bakımından vekalet teorisi ve kaynak bağımlılığ teorisini destekler nitelikte olup, literatürde Jackling ve Johl' un 2009' da Hindistan' da yaptığı çalışma ile, Rehman ve Shah' in 2013' de Pakistan' da yaptığı çalışma ile, Swastika' nın 2013 yılında Endonezya' da yaptığı çalışma ile, Topal ve Doğan’ in 2014 yılında Türkiye' de yaptığı çalışma ile, Okan ve diğerlerinin 2014 yılında Türkiye' de yaptığı çalışma ile, Ntim ve diğerlerinin 2015 yılında Güney Afrika' da yaptığı çalışma ile ve Aytekin ve Sönmez' in 2016' da Türkiye' de yaptı̆̆ 1 


\section{Ö.ATILGAN}

çalışmanın sonuçları ile benzerlik göstermektedir. Bu çalışmanın sonuçlarının Türkiye' de yapılan çalışmaların sonuçları ile örtüşüyor olması, Türkiye' de vekalet ve kaynak bağımlılığı teorilerinin yönetim kurulu büyüklüğü bağlamında geçerli olduğunu ortaya koymaktadır. Şirketler büyük yönetim kurulları oluşturarak yöneticilerin kendi çıkarlarını, paydaş çıkarlarının önüne geçirmesini engellemekte, şirketin gerekli kaynaklara ulaşmasını kolaylaştırmakta ve sonuç olarak finansal performanslarını arttırabilmektedir.

Çalışmanın sonuçlarından ikincisi ise, bağımsız yönetim kurulu üye oranı arttıkça, finansal performansın kısmen de olsa azalış göstermesidir. Bağımsız yönetim kurulu üye oranı ile ROA arasında 0,05 anlamlılık düzeyinde zayıf ($0,161)$ ve negatif bir ilişki tespit edilmiştir. Bağımsız yönetim kurulu üye oranı ile finansal performans ilişkisi bakımından bu çalışmanın sonucu vekalet teorisi ve kaynak bağımlılığ teorisini desteklememekle birlikte, literatürde Lam ve Lee' nin 2008' de Hong Kong' da yaptığı çalışma ile, Şengür ve Püskül' ün 2011' de Türkiye' de yaptığı çalışma ile, Koerniadi ve Tourani-Rad' in 2012' de Yeni Zelanda' da yaptığı çalışma ile, Bhagat ve Bolton' un 2013 yılında ABD' de yaptığı çalışmanın sonuçları ve Okan ve diğerlerinin 2014 yılında Türkiye' de yaptığı çalışmanın sonuçları ile benzerlik göstermektedir. $\mathrm{Bu}$ çalışmanın sonucunun bağımsız yönetim kurulu üye oranı ile negatif finansal performans ilişkisi bağlamında Türkiye' de yapılan çalışmaların sonuçları ile örtüşüyor olması, Türkiye' de borsada işlem gören şirketlerin yönetim kurullarında yer alan bağımsız yönetim kurulu üyelerinin görev yaptıkları şirketle ilgili bilgi, beceri ve donanıma bağımlı üyeler kadar sahip olmadıkları, şirkete kadar zaman ayıramadıkları ve dolayısıyla şirketin finansal performansını olumsuz yönde etkilediklerine işaret etmektedir.

Çalışmanın üçüncü sonucu ise, yönetim kurulunda kadın üye oranı arttıkça, finansal performansın kısmen ve az da olsa azalış göstermesidir. Yönetim kurulunda kadın üye oranı ile ROS arasında 0,05 anlamlılık düzeyinde zayıf (0,122 ) ve negatif yönlü bir ilişki ve yönetim kurulunda kadın üye oranı ile EBITDA Margin arasında zayıf $(-0,126)$ ve negatif yönlü bir ilişki tespit edilmiştir. 
Yönetim kurulunda kadın üye oranı ile finansal performans ilişkisi bakımından bu çalışmanın sonucu kaynak bağımlılı̆ğ teorisini desteklememekle birlikte, literatürde Adams ve Ferreira' nın 2009 yılında ABD’ de yaptığı çalışma ile, Alvarez' in 2010 yılında İspanya' da yaptığı çalışma ile ve Böhren ve Ström' ün 2010 yılında Norveç' te yaptığı çalışmanın sonuçları ile benzerlik göstermektedir. Çalışmada tespit edilen yönetim kurulunda kadın üye oranı ile negatif finansal performans ilişkisi sonucu Türkiye' de borsada işlem gören şirketlerin kadın yönetim kurulu üyelerinin sayılarını arttırsa bile, kadınlarla bilgi paylaşma, kadınlara yetki, insiyatif ve güç kullandırma konusunda yetersiz kaldıkları ve bu sebepten dolayı da kadın üye sayılarını arttırdıkça, şirketle ilgili yeterli donanıma sahip olmayan kadın üyelerin finansal performansı olumsuz etkilediklerine işaret etmektedir.

Öte yandan, kurumsal yönetim literatürü incelendiğinde, yönetim kurulu yapısı ile ilgili olan yönetim kurulu büyüklüğü, yönetim kurulunda bağımsız üye oranı ve yönetim kurulunda kadın üye oranı değişkenlerinin pozitif ya da negatif yönde olsun finansal performans ile düşük bir ilişki içinde olduğu sonucuna varılmıştır. Bunun nedeninin ise, finansal performans ile ilişkisi olan ve yönetim kurulu yapısından farklı bir çok farklı değişkenin mevcut olması olgusudur.

Bu çalışma, örneklem büyüklüğü ve güncel verileri kullanması bakımından özellikle Türkiye' deki kurumsal yönetim literatürüne katk1 yapacağı düşünülmektedir. Bundan sonra yapılacak çalışmalarda ise, yönetim kurulu yapısı bu çalışmada kullanılan değişkenlerin yanında icrac1/ icracı olmayan yönetim kurulu başkanı, yönetim kurulunda aileden üye oranı, yönetim kurulunda içeriden/ dışardan üye oranı gibi başka değişkenlerle birlikte ele alınabilir ve bu yeni değişkenlerin finansal performans ile ilişkisi incelenebilir.

\section{KAYNAKÇA}

ADAMS R., FERREIRA D. (2009) “Women in the Boardroom and Their Impact on Governance and Performance", Journal of Financial Economics, 94 (2), 291309. 


\section{Ö.ATILGAN}

AKAL Z. (2002), İşletmelerde Performans Ölçüm ve Denetimi: Çok Yönlü Performans Göstergeleri, Milli Produktivite Merkezi Yayınları No:473, 5. Bask1, Ankara.

AKDOĞAN Y.M.,BOYACIOĞLU M.A. (2010), “Türkiye' de Kurumsal Yönetim: Genel Bir Değerlendirme”, Selçuk Üniversitesi Sosyal Bilimler Enstitüsü Dergisi, 24,11-30.

AKGÜÇ Ö. (1998), Finansal Yönetim, Avcıol Yayınları, Yenilenmiş 7. Bask1, İstanbul

ALCALDE A., FAVERO L.P.L., TAKAMATSU R.T. (2013), “ EBITDA margin in Brazilian Companies Variance Decomposition and Hierarchical Effects", Contaduria y Administracion, 58(2), 201.

ALDRICH H.E., PFEFFER J. (1976), "Environment Of Organizations", Annual Review Of Sociology, 2(1),79-105.

ALVAREZ I.G., GARCIA-SANCHEZ I.M, RODRIGUEZ-DOMINGUEZ L. (2010), “ The Influence of Gender Diversity On Corporate Performance”, Spanish Accounting Review, 13(1),53-88.

ANDERSON R.C., REEB D.M. (2004), “ Board Composition: Balancing Family Influence in S\&P Firms", Administrative Science Quarterly, 49(2), 209-237. 
AROSA B., T. ITTURALDE T., MASEDA A. (2010) “ Outsiders On The Board Of Directors And Firm Performance: Evidence From Spanish Non-Listed Family Firms", Journal Of Family Business Strategy, 1(1),236-245.

ARSLANTAŞ C.C. (2012), Kurumsal Yönetimin Yönetim Kuruluna Yansımaları, Beta Basım A.Ş, 1.Baskı, İstanbul.

ARSLANTAŞ C.C., FINDIKLI M.A. (2010), “IMMKB-50’ de Yer Alan Şirketlerin Yönetim Kurulu Yapılanmaları”, İstanbul Üniversitesi İşletme Fakültesi Dergisi, $39(2), 258-275$.

AYCAN Z. (2004), “ Key Success Factors for Women in Management in Turkey”, Applied Psychology, 53(3),453-477.

AYTEKİN M., SÖNMEZ A.R. (2016), “ Kurumsal Yönetim Uygulamalarının İşletme Performansına Etkisi”, Türk Sosyal Bilimler Araştırmaları Dergisi, $1(2), 32-42$.

BAYSINGER B.D., H.N. BUTLER H.N. (1985), "Corporate Governance and Board of Directors: Performance Effects of Changes in Board Composition", Journal of Law Economics and Organization, 1(1),101-124.

BEINER S., DROBETZ W., SCHMID F., ZIMMERMANN H. (2004) “ Is Board Size an Independent Corporate Governance Mechanism ? “, Kyklos, 57(3), 327356. 


\section{Ö.ATILGAN}

BOYD B. (1990), “ Corporate Linkages and Organizational Environment: A Test of the Resource Dependence Model, Strategic Management Journal, 11(6), 419430 .

BÖHREN O., STROM O. (2010), "Governance and Politics: Regulating Independence and Diversity in the Board Room”, Journal of Business Finance and Accounting, 37(9), 1281-1308.

BURGESS Z., THARENON P. (2002), “Women Board Directors”, Journal of Business Ethics, 37(1), 39-49.

CANBAŞ S., DOĞUKANLI H., DÜZAKIN H., İSKENDEROĞLU Ö. (2005), “ Performans Ölçümünde Tobin's q Oranının Kullanılması: Hisse Senetleri İMKB' de İşlem Gören Sanayi İşletmeleri Üzerinde Bir Deneme", Muhasebe ve Finansman Dergisi, 28, 24-36.

CONYON M.J., PECK S.I. (1998) “ Board size and corporate performance: evidence from European countries", The European Journal of Finance, 4(3), 291304.

DALTON D.R., DAILY C.M., ELLSTRAND A.E., JOHNSON J.L. (1998), “ Meta- Analytic Reviews of Board Composition, Leadership Structure, And Financial Performance", Strategic Management Journal, 19, 269-290.

DARMADI S. (2010), “ Board Diversity and Firm Performance: The Indonesian Evidence", Corporate Ownership and Control Journal, 8, 1627-1637. 
DEHAENE A., VUYST V.D., OOGHE H. (2001), "Corporate Performance and Board Structure in Belgian Companies”, Long Range Planning, 34(3), 392-393.

DONALDSON L. (1990), “ The Etheral Hand: Organizational Economics and Management Theory", Academy of Management Review, 15(3), 369-81.

EISENHARDT K.M (1989), "Agency Theory: An assesment and review", Academy of Management Review,14(1),57-74.

FAMA E.F. (1980), "Agency Problems and the Theory of the Firm”, Journal of Political Economy, 88(2),288-307.

FAMA E.F., JENSEN M. (1983), “Agency Costs and Residual Claims”, Journal of Law and Economics, 26, 327-349.

FREEMANN R.E., REED D. L. (1983), “ Stockholders and Stakeholders: A New Perspective on Corporate Governance", California Management Review, 25, 88106.

HILLMANN A., CANELlA A., PAETZOLD R. (2000), “The Resource Dependence Role of Corporate Directors: Strategic Adaptation of Board Composition in Response to Environmental Change", Journal of Management Studies, 37(2), 235-256. 


\section{Ö.ATILGAN}

JACKLING B., JOHL S. (2009), “ Board Structure and Firm Performance: Evidence from India's Top Companies”, Corporate Governance: An International Review, 17(4), 492-509.

JOHL S.K., JOHL S., B.J. COOPER B.J. (2015), “ Board Characteristics and Firm Performance: Evidence from Malaysian Public Listed Firms", Journal of Economics, Business and Management, 3(2), 239-243.

KAPLAN R.S., NORTON D.P. (1996), “Balanced Scorecard”, New York.

KARAYEL M., DOĞAN M. (2014), “ Yönetim Kurulunda Cinsiyet Çeşitliliği ve Finansal Performans İlişkisi: BİST 100 Şirketlerinde Bir Araştırma”, Süleyman Demirel Üniversitesi İktisadi ve İdari Bilimler Fakültesi Dergisi, 19(2), 75-88.

KILIÇ İ., EMIR O., KILIÇ G. (2011), “ Bulanık Kümeleme Analizi ile Ülkelerin Turizm İstatistikleri Bakımından Sınıflandırılması”, İstatistikçiler Dergisi, 4(1),32.

KIEL G.C., NICHOLSON G.J. (2003), “ Board Composition and Corporate Performance: How the Australian Experience Informs Contrasting Theories of Corporate Governance", Corporate Governance: An International Review, 11(3), 189-205.

KOERNIADI H., TOURANI-RAD A. (2012), “ Does Board Independence Matter ? Evidence from New Zealand", Australasian Accounting, Business and Finance Journal, 6(2), 3-18. 
LAM T.Y., LEE S.K. (2008), "CEO duality and firm performance: evidence from Hong Kong", Corporate Governance: The international journal business in society, 8(3), 299-316.

NICHOLSON G.J, G.C. KIEL G.C. (2007), “ Can Directors Impact Performance A Case Based Test of Three Theoris of Corporate Governance", Corporate Governance: An International Review, 15(1), 585-608.

NTIM C.G, OPONG K.K, DANBOLT J.(2015), "Board size, corporate regulations and firm valuation in an emerging market: a simultaneous equation approach", International Review of Applied Economics, 29(2),194-220.

OCAK M. (2013), “ Yönetim Kurulu ve Üst Yönetimde Yer Alan Kadınların Finansal Performansa Etkisi: Türkiye' ye İlişkin Bulgular”, Muhasebe ve Finansal Dergisi, 107-126.

OKAN T., SARI S., NAS T.İ (2014), "Yönetim Kurulu Yapısı ile Finansal Performans Arasındaki İlişkide Uluslararası Çeşitlenmenin Aracılık Etkisi”, İ.Ü. İşletme Fakültesi İşletme İktisadı Enstitüsü Yönetim Dergisi, 25(77), 39-78.

OTLUOĞLU E., SARI E.S., OTLUOĞLU Ö.Ç. (2016), “ Yönetim Kurulu Çeşitliliğinin Finansal Performansa Etkisi: BİST 100 Üzerinde Bir Araştırma, Uluslararası Sosyal Araştırmalar Dergisi, 9(46),749-758. 


\section{Ö.ATILGAN}

ÖKTEM Ö.Y, GÖKŞEN N.S. (2010), “ Kurumsal Baskılar ve Aile Kontrolündeki Şirket Gruplarına Bağlı Şirketlerin Yönetim Kurulu Kompozisyonlarındaki Değişim”, “, T.C. İstanbul Kültür Üniversitesi 4. Aile İşletmeleri Kongresi Kongre Kitab1, İstanbul.

PERVAN M., VISIC J. (2012), "Influence of Firm Size On Its Business Success", Croatian Operational Research Review, 3(1),.218.

PFEFFER J. (1972), " Size and Composition of Corporate Boards of Directors : The Organization and its Environment", Administrative Science Quarterly, $17(2), 218-228$

RAMDANI D., VAN WITTELOOSTUIJN A. (2010), “ The Impact of Board Independence and CEO Duality on Firm Performance: A Quatile Regression Analysis for Indonesia, Malaysia, South Korea and Thailand", British Journal of Management, 21,607-626.

SPK (2011), "Kurumsal Yönetim İlkelerinin Belirlenmesine ve Uygulanmasina İlişkin Tebliğ”, Seri:IV, No:56, İstanbul.

SPK (2012), "Kurumsal Yönetim İlkelerinin Belirlenmesine ve Uygulanmasına İlişkin Tebliğ”, Seri:IV, No:57, İstanbul.

SPK, (2014), "Kurumsal Yönetim Tebliği (II-17.1)”, Sayı: 28871, İstanbul. 
SWASTIKA D.L.T. (2013), "Corporate Governance, Firm Size, Earnings Management: Evidence in Indonesia Stock Exchange”, IOSR Journal of Business and Management, 10(4),77-82.

ŞENGÜR E.D., PÜSKÜL S.Ö. (2011), “ İMKB Kurumsal Yönetim Endeksindeki Şirketlerin Yönetim Kurulu Yapısı ve İşletme Performansının Değerlendirilmesi”, Dumlupınar Üniversitesi Sosyal Bilimler Dergisi, 31, 45.

TOPAL Y., DOĞAN M. (2014), “ Impact of Board Size on Financial Performance: The Case of BIST Manufactoring Industry", International Journal of Business Management and Economic Research, 5(4),74-79.

TOROMAN C., ABDİOĞLU H. (2008), “ İMKB Kurumsal Yönetim Endeksinde Yer Alan Şirketlerin Kurumsal Yönetim Uygulamalarında Zayıf ve Güçlü Yanları: Derecelendirme Raporlarının İncelenmesi”, Muhasebe ve Finansman Dergisi, 40, 96-109.

TOROMAN C., KÖRPİ M. (2015), “ Firma Değerinin Piyasa Çarpanları ile Tahmin Edilmesi: BIST Dokuma, Giyim Eşyası Ve Deri Sanayii Sektöründe Bir Uygulama", Muhasebe ve Finansman Dergisi, 1(66), 45.

TÜKENMEZ M., SUSMUŞ T., ÖZKAN S., KUTAY N., EVRIMM P., BAKLACI H.F.,YÜCEL T.,ÖZKOL E., DURUKAN B., YÜKÇÜ S. (1999), "Muhasebe Sistemi Uygulama Genel Tebliği’ ne Göre Finansal Yönetim”, Cem Ofset, Ankara. 


\section{Ö.ATILGAN}

UCHIDA K. (2011), “ Does corporate board downsizing increase shareholder value ? Evidence from Japan", International Review of Economics \& Finance, 20(4), 562-573.

WAGNER J.A.,STIMPERT J.L, FUBARA E.I. (1998), “ Board Composition And Organizational Performance: Two Studies Of Insider/Outsider Effects", Journal of Management Studies, 35(5),655-676.

YERMACK D. (1996), “ Higher market valuation of companies with a small board of directors", Journal of Financial Economics, 40(2), 185-211.

ZAHRA S.A., PEARCE J.A.(1989), “ Boards of Directors and Corporate Financial Performance", A Review and Integrative Model”, Journal of Management, 15(2), 291-334.

Ek 1. YK Büyüklüğü Finansal Performans İlişkisini İnceleyen Çalışmalar

\begin{tabular}{|l|l|r|r|l|l|l|}
\hline Yazar & Yıl & Yer & $\begin{array}{r}\text { Şirket } \\
\text { Sayısı }\end{array}$ & $\begin{array}{l}\text { Bağımsız } \\
\text { Değişkenler }\end{array}$ & $\begin{array}{r}\text { Bağımlı } \\
\text { Değişkenler }\end{array}$ & $\begin{array}{c}\text { İlişki } \\
\text { Sonucu }\end{array}$ \\
\hline Yermack & 1996 & ABD & 452 & $\begin{array}{l}\text { Bağımsız } \\
\text { YK } \\
\text { Üye Oranı, } \\
\text { YK } \\
\text { Büyüklüğü }\end{array}$ & Tobin's q, & $\begin{array}{l}\text { YK } \\
\text { ROA, } \\
\text { RÖyüklüğü- } \\
\text { ROA(negati } \\
\text { f/zayıf), } \\
\text { YK } \\
\text { Büyüklüğü- } \\
\text { ROS(negatif } \\
\text { /zayıf), }\end{array}$ \\
\hline
\end{tabular}


Dokuz Eylül Üniversitesi İktisadi ve İdari Bilimler Fakültesi Dergisi Cilt:32, Sayl:2, Yll:2017, ss. 315-354

\begin{tabular}{|c|c|c|c|c|c|c|}
\hline $\begin{array}{l}\text { Conyon ve } \\
\text { Peck }\end{array}$ & 1998 & $\begin{array}{l}\text { Fransa, } \\
\text { Hollanda, } \\
\text { Danimar } \\
\text { ka, } \\
\text { İtalya, } \\
\text { İngiltere }\end{array}$ & $\begin{array}{c}60 \\
\text { (Fransa) } \\
21 \\
\text { (Holla } \\
\text { nda) } \\
22(\mathrm{Da} \\
\text { nimarka } \\
21 \\
\text { (İtalya) } \\
481 \\
\text { (İngiltere) }\end{array}$ & $\begin{array}{c}\text { YK } \\
\text { Büyüklüğü }\end{array}$ & $\begin{array}{l}\text { Tobin's q, } \\
\text { ROE }\end{array}$ & $\begin{array}{c}\text { YK } \\
\text { Büyüklüğ̈̈- } \\
\text { Tobin's q } \\
\text { (negatif/zayı } \\
\text { f), } \\
\text { YK } \\
\text { Büyüklüğü- } \\
\text { ROE } \\
\text { (negatif/ } \\
\text { zayıf), }\end{array}$ \\
\hline Dehaene & 2001 & Belçika & 122 & \begin{tabular}{l}
\multicolumn{2}{c}{ Bağımsız } \\
YK Üye \\
Oranı
\end{tabular} & $\begin{array}{l}\text { ROA, } \\
\text { ROE }\end{array}$ & $\begin{array}{l}\text { Bağımsız } \\
\text { YK } \\
\text { Üye Oranı- } \\
\text { ROE } \\
\text { (pozitif/zayı } \\
\text { f) }\end{array}$ \\
\hline $\begin{array}{l}\text { Kiel ve } \\
\text { Nicholson }\end{array}$ & 2003 & $\begin{array}{l}\text { Avustral } \\
\text { ya }\end{array}$ & 348 & \begin{tabular}{l}
\multicolumn{2}{c}{ Bağımsız } \\
YK Üye \\
Oranı, YK \\
Büyüklüğü
\end{tabular} & ROA & - \\
\hline $\begin{array}{l}\text { Lam ve } \\
\text { Lee }\end{array}$ & 2008 & $\begin{array}{l}\text { Hong } \\
\text { Kong }\end{array}$ & 123 & \begin{tabular}{l}
\multicolumn{2}{c}{ Bağımsız } \\
YK Üye \\
Oranı, YK \\
Büyüklüğü
\end{tabular} & $\begin{array}{l}\text { ROE, } \\
\text { ROA }\end{array}$ & $\begin{array}{l}\text { Bağımsız } \\
\text { YK Üye } \\
\text { Oranı-ROA } \\
\text { (negatif/zayı } \\
\text { f), } \\
\text { YK } \\
\text { Büyüklüğü- } \\
\text { ROA }\end{array}$ \\
\hline
\end{tabular}




\section{Ö.ATILGAN}

\begin{tabular}{|c|c|c|c|c|c|c|}
\hline & & & & & & $\begin{array}{l}\text { (negatif/zay1 } \\
\text { f), }\end{array}$ \\
\hline $\begin{array}{l}\text { Adams ve } \\
\text { Ferreira }\end{array}$ & 2009 & $\mathrm{ABD}$ & 1939 & $\begin{array}{l}\text { YK' da } \\
\text { kadın } \\
\text { oranı, }\end{array}$ & $\begin{array}{r}\text { ROA, } \\
\text { Tobin's q }\end{array}$ & $\begin{array}{l}\quad \text { YK' da } \\
\text { kadın üye } \\
\text { oranı- } \\
\text { ROA(negati } \\
\text { f/zayıf) }\end{array}$ \\
\hline $\begin{array}{l}\text { Jackling } \\
\text { ve Johl }\end{array}$ & 2009 & Hindistan & 180 & $\begin{array}{l}\text { Bağımsız } \\
\text { YK Üye } \\
\text { Oranı, YK } \\
\text { Büyüklüğü }\end{array}$ & ROA & $\begin{array}{l}\quad \text { YK } \\
\text { Büyüklüğ̈̈- } \\
\text { ROA } \\
\text { (pozitif/zayı } \\
\text { f) }\end{array}$ \\
\hline $\begin{array}{l}\text { Ramdani } \\
\text { ve van } \\
\text { Witteloost } \\
\text { uijn }\end{array}$ & 2010 & $\begin{array}{l}\text { Endonez } \\
\text { ya } \\
\text { Güney } \\
\text { Kore } \\
\text { Malezya } \\
\text { Tayland }\end{array}$ & 313 & \begin{tabular}{l}
\multicolumn{2}{c}{ Bağımsız } \\
YK Üye \\
Oranı
\end{tabular} & ROA & $\begin{array}{l}\text { Bağımsız } \\
\text { YK Üye } \\
\text { Oranı-ROA } \\
\text { (pozitif/zayı } \\
\text { f) }\end{array}$ \\
\hline Darmadi & 2010 & $\begin{array}{l}\text { Endonez } \\
\text { ya }\end{array}$ & 169 & \begin{tabular}{l}
\multicolumn{2}{c}{ YK'da } \\
kadın üye \\
oranı
\end{tabular} & ROA & - \\
\hline Alvarez & 2010 & İspanya & 117 & \begin{tabular}{l}
\multicolumn{2}{c}{ YK'da } \\
kadın üye \\
oranı
\end{tabular} & $\begin{array}{c}\text { ROA, } \\
\text { ROE, ROS }\end{array}$ & $\begin{array}{l}\text { YK'da } \\
\text { kadın üye } \\
\text { oranı-ROA } \\
\text { (negatif/orta } \\
\text { ), } \\
\text { YK'da }\end{array}$ \\
\hline
\end{tabular}


Dokuz Eylül Üniversitesi İktisadi ve İdari Bilimler Fakültesi Dergisi Cilt:32, Sayl:2, Yll:2017, ss. 315-354

\begin{tabular}{|c|c|c|c|c|c|c|}
\hline & & & & & & $\begin{array}{l}\text { kadın üye } \\
\text { oranı-ROE } \\
\text { (negatif/orta } \\
\text { ) } \\
\qquad \text { YK'da } \\
\text { kadın üye } \\
\text { oranı-ROS } \\
\text { (negatif/orta } \\
\text { ) }\end{array}$ \\
\hline $\begin{array}{l}\text { Böhren } \\
\text { ve Ström }\end{array}$ & 2010 & Norveç & 203 & $\begin{array}{l}\text { YK'da } \\
\text { kadın üye } \\
\text { oranı }\end{array}$ & $\begin{array}{l}\text { ROA, } \\
\text { ROS, } \\
\text { Tobin's q }\end{array}$ & $\begin{array}{l}\text { YK'da } \\
\text { kadın üye } \\
\text { oranı-ROA } \\
\text { (negatif/zayı } \\
\text { f), } \\
\text { YK'da } \\
\text { kadın üye } \\
\text { oranı-ROE } \\
\text { (negatif/zayı } \\
\text { f) } \\
\text { YK'da } \\
\text { kadın üye } \\
\text { oranı-ROS } \\
\text { (negatif/zayı } \\
\text { f) }\end{array}$ \\
\hline Uchida & 2011 & Japonya & 775 & $\begin{array}{c}\text { YK } \\
\text { Büyüklüğü }\end{array}$ & ROA & - \\
\hline $\begin{array}{l}\text { Şengür } \\
\text { ve Püskül }\end{array}$ & 2011 & Türkiye & 24 & $\begin{array}{l}\text { Bağımsız } \\
\text { YK Üye } \\
\text { Oranı }\end{array}$ & $\begin{array}{l}\text { ROA, } \\
\text { ROE, PER, } \\
\text { EPS,SR }\end{array}$ & $\begin{array}{l}\quad \text { Bağımsı } \\
\text { z YK Üye } \\
\text { Oranı-ROA } \\
\text { (negatif/zayı }\end{array}$ \\
\hline
\end{tabular}




\section{Ö.ATILGAN}

\begin{tabular}{|c|c|c|c|c|c|c|}
\hline & & & & & & $\begin{array}{l}\text { f) } \\
\quad \text { Bağımsı } \\
\text { z YK Üye } \\
\text { Oranı-ROE } \\
\text { (negatif/zayı } \\
\text { f) }\end{array}$ \\
\hline $\begin{array}{l}\text { Koerni } \\
\text { adi ve } \\
\text { Tourani- } \\
\text { Rad }\end{array}$ & 2012 & $\begin{array}{r}\text { Yeni } \\
\text { Zelanda }\end{array}$ & 182 & \begin{tabular}{l}
\multicolumn{2}{c}{ Bağımsız } \\
YK Üye \\
Oranı, YK \\
Büyüklüğü
\end{tabular} & $\begin{array}{l}\text { ROE, } \\
\text { ROA }\end{array}$ & $\begin{array}{l}\quad \text { Bağımsı } \\
\text { z YK Üye } \\
\text { Oranı-ROA } \\
\text { (negatif/zayı } \\
\text { f), } \\
\quad \text { Bağımsı } \\
\text { z YK Üye } \\
\text { Oranı-ROE } \\
\text { (negatif/zayı } \\
\text { f), } \\
\quad \text { YK } \\
\text { Büyüklüğü- } \\
\text { ROA } \\
\text { (negatif/zayı } \\
\text { f) }\end{array}$ \\
\hline Ocak & 2013 & Türkiye & 111 & \begin{tabular}{l}
\multicolumn{2}{c}{ YK'da } \\
kadın üye \\
oranı
\end{tabular} & ROA & $\begin{array}{l}\text { YK'da } \\
\text { kadın üye } \\
\text { oranı-ROA } \\
\text { (pozitif/zayı } \\
\text { f), }\end{array}$ \\
\hline Swastika & 2013 & $\begin{array}{l}\text { Endozen } \\
\text { yа }\end{array}$ & 51 & $\begin{array}{c}\text { YK } \\
\text { Büyüklüğü }\end{array}$ & ROA & $\begin{array}{l}\quad \text { YK } \\
\text { Büyüklüğ̈̈- } \\
\text { ROA } \\
\text { (pozitif/zayı }\end{array}$ \\
\hline
\end{tabular}


Dokuz Eylül Üniversitesi İktisadi ve İdari Bilimler Fakültesi Dergisi Cilt:32, Sayl:2, Yll:2017, ss. 315-354

\begin{tabular}{|c|c|c|c|c|c|c|}
\hline & & & & & & f), \\
\hline $\begin{array}{r}\text { Karaye } \\
\text { 1 ve Doğan }\end{array}$ & 2014 & Türkiye & 100 & \begin{tabular}{l}
\multicolumn{2}{c}{ YK'da } \\
kadın üye \\
oranı
\end{tabular} & $\begin{array}{c}\text { ROE, } \\
\text { Tobin's q }\end{array}$ & - \\
\hline $\begin{array}{r}\text { Topal } \\
\text { ve Doğan }\end{array}$ & 2014 & Türkiye & 136 & $\begin{array}{c}\text { YK } \\
\text { Büyüklüğü }\end{array}$ & $\begin{array}{l}\text { ROE, } \\
\text { ROA }\end{array}$ & $\begin{array}{l}\text { YK } \\
\text { Büyüklüğü- } \\
\text { ROA } \\
\text { (pozitif/zayı } \\
\text { f), }\end{array}$ \\
\hline Okan vd. & 2014 & Türkiye & 83 & $\begin{array}{l}\text { YK } \\
\text { Büyüklüğü, } \\
\text { Bağımsız } \\
\text { YK Üye } \\
\text { Oranı }\end{array}$ & ROA & $\begin{array}{l}\quad \text { YK } \\
\text { Büyüklüğü- } \\
\text { ROA } \\
\text { (pozitif/zayı } \\
\text { f), } \\
\qquad \text { Bağımsı } \\
\text { z YK Üye } \\
\text { Oranı } \\
\text { (negatif/zayı } \\
\text { f) }\end{array}$ \\
\hline Johl vd. & 2015 & Malezya & 700 & \begin{tabular}{l}
\multicolumn{2}{c}{ Bağımsız } \\
YK Üye \\
Oranı, YK \\
Büyüklüğü
\end{tabular} & ROA & $\begin{array}{l}\quad \text { YK } \\
\text { Büyüklüğü- } \\
\text { ROA } \\
\text { (pozitif/zayı } \\
\text { f), }\end{array}$ \\
\hline Ntim vd. & 2015 & $\begin{array}{l}\text { Güney } \\
\text { Afrika }\end{array}$ & 169 & $\begin{array}{c}\text { YK } \\
\text { Büyüklüğüu }\end{array}$ & $\begin{array}{l}\text { Tobin's } \\
\text { q, ROA }\end{array}$ & $\begin{array}{l}\quad \text { YK } \\
\text { Büyüklüğü- } \\
\text { ROA } \\
\text { (pozitif/zayı } \\
\text { f), }\end{array}$ \\
\hline
\end{tabular}




\section{Ö.ATILGAN}

\begin{tabular}{|c|c|c|c|c|c|c|}
\hline $\begin{array}{l}\text { Aytekin ve } \\
\text { Sönmez }\end{array}$ & 2016 & Türkiye & 35 & \begin{tabular}{l}
\multicolumn{2}{c}{ Bağımsız } \\
YK Üye \\
Oranı, YK \\
Büyüklüğü
\end{tabular} & $\begin{array}{l}\text { ROE, } \\
\text { ROA }\end{array}$ & $\begin{array}{l}\quad \text { YK } \\
\text { Büyüklüğü- } \\
\text { ROE } \\
\text { (pozitif/zay1 } \\
\text { f) }\end{array}$ \\
\hline $\begin{array}{l}\text { Otluoğlu } \\
\text { vd. }\end{array}$ & 2016 & Türkiye & 49 & \begin{tabular}{l}
\multicolumn{2}{c}{ YK'da } \\
kadın üye \\
oranı
\end{tabular} & $\begin{array}{l}\text { ROA, } \\
\text { ROE, } \\
\text { Tobin's q }\end{array}$ & \begin{tabular}{l}
\multicolumn{1}{c}{ YK'da } \\
kadın üye \\
oranı-ROE \\
(pozitif/zayı \\
f), \\
$\quad$ YK'da \\
kadın üye \\
oranı-ROE \\
(negatif/zay1 \\
f),
\end{tabular} \\
\hline
\end{tabular}

